\title{
Biographical Register
}

Adrian, Edgar Douglas (1889-1977), began lecturing on the nervous system at Cambridge University in 1919, and was made Fellow of the Royal Society in 1923. In 1925 he began investigating the sense organs by electrical methods, and in 1929 was elected Foulerton Professor of the Royal Society. In 1937 he succeeded Sir Joseph Barcroft as professor of physiology at the University of Cambridge, a post which he held until 1951, when he became Master of Trinity College, Cambridge. Adrian pioneered the study of nerve impulses and electrical discharges in nerve fibres, which led to his being credited with providing a new quantitative basis of nervous behaviour. He also studied impulses caused by stimuli likely to cause pain, as well as the electrical activity of the brain. His work opened up new fields of investigation in the study of epilepsy and other lesions of the brain. For his work on the functions of neurones Adrian was awarded, jointly with Sir Charles Sherrington, the Nobel Prize for Physiology or Medicine for 1932. Among Adrian's numerous publications are The basis of sensation (1927) and The physical background of perception (1947).

Allers, Rudolf (1883-1963), worked from 1918 to 1938 at the Medical School of the University of Vienna, moving from physiology towards psychiatry in the late 1920s. He emigrated to the USA in 1938, where he taught philosophy for a decade at the Catholic University of America. He then became professor of philosophy at Georgetown University, and in 1955 was a Fulbright lecturer in Paris, Toulouse, Geneva and Vienna, becoming professor emeritus at Georgetown University in 1957. His books include The psychology of character (1931), Sex psychology in education (1937) and Existentialism and psychiatry (1961).

Ancel, Albert-Paul (1873-1961), was professor of embryology at Strasbourg University from 1919 onwards. He was a pioneer in sexual endocrinology, and received the Prix du Prince de Monaco in 1937.

Angyal, Lajor (?-?), worked on schizophrenia and insulin shock in Budapest, and contributed to the clarification of the effect mechanisms of chlorpromazine and imipramine.

Antoni, Nils Ragnar Eugene (1887-?), was professor of neurology at the Karolinska Institute at Stockholm University from 1931; and later director of the University Clinic.

Astachoff: could be Nicolai Astachoff (1875-1941), who was a full professor at the Leningrad Institute for Medical Education between 1921 and 1928, and in 1929 became professor for dental health. Until his death he held the chair in stomatology at the Leningrad Institute for Medical Education. 
Bach: could be $\mathbf{A} \mathbf{N}$ Bach, a physiological chemist who went to Geneva after the Russian Revolution, and worked on albuminosis in 1937. Lewis refers to him as the "late" Prof. Bach, however, so it is possible he is referring to another person.

Baruk, Henri (1897-1999), found with Henk de Jong that mescaline could freeze laboratory animals into cataleptic positions ( $\mathrm{H} \mathrm{H}$ de Jong, 'Die experimentelle Katatonie', Zentralblatt für die Gesamte Neurologie und Psychiatrie, 1932, 139: 468 ff.; and $\mathrm{H} \mathrm{H}$ de Jong and $\mathrm{H}$ Baruk, La catatonie expérimentale par la bublocapnine (1930)). Baruk was a candidate for the professorship of psychiatry at the University of Paris psychiatry department in the Hôpital Sainte-Anne in 1946, but it was given to Jean Delay. Baruk's work in the 1950s focused on the phenothiazines' ability to induce catalepsy.

Bastianelli: it seems that Lewis is talking about Giuseppe Bastianelli (1862-1959), the Italian surgeon, and that the brother he mentions is Raffaele Bastianelli (1863-1961), professor of surgery and director of the Surgical Clinic in Rome, a pioneer of neurosurgery.

Bechterev, Vladimir Michaelovitsch (1857-1927), was chief exponent and founder of the school of psychiatry built up around Pavlov's work. After studying abroad under Émile DuBois-Reymond, Wilhelm Wundt, Paul Flechsig and Jean Martin Charcot, Bechterev established a psychophysiological laboratory in Kazan University. From 1893 he worked in St Petersburg on the neuropathology and anatomy of the nervous system.

Benedek, László (1887-Second World War), was made professor of neurology and psychiatry at Debrecen University in 1921; and professor of neurology and psychiatry and director of the University Hospital for Neurology and Psychiatry at Budapest University from 1936 onwards. He did lasting work in the field of organic brain syndromes and on Korsakov's syndrome.

Bergmark, Gustaf (1881-?), was made professor of internal medicine at Uppsala University from 1921 onwards.

Berlucchi: this could be Carlo Berlicchi (1897-?) who was titular professor at Parma University 1935-6; and was full professor of mental and nervous diseases from 1936 onwards.

Bersot, H (?-1955), was director of the Clinique Bellevue at Landeron (Neuchâtel) at the time of Lewis's visit.

Bertrand, Ivan (1893-?), a Belgian neuropathologist, was in charge of the histopathological laboratory at La Salpêtrière when Lewis visited Paris. His name is associated with the Guillain-Bertrand-Lereboullet syndrome, one of the choreiform syndromes.

Berze, Josef (1866-1957), was associate professor of psychiatry at the University of Vienna in 1921. In 1912 he was made director of the Lower Austria Provincial Asylum at Klosterneuburg in 1912; and of the Provincial Asylum in Steinhof in 1919, where he stayed until 1928.

Besta, Carlo (1876-1940), was a consultant neurologist in the S. Ambrogio military hospital in Milan in 1914, and his experiences led him to set up a neurosurgical hospital 


\section{Biographical Register}

in Guastalla. After the war, Besta taught in Messina and then was made chair of the neuropsychiatric clinic in Milan.

Beule, Fritz de (1880-1949), was professor of surgical pathology at Ghent in 1919. From 1924 until his death he was director of the University Surgical Clinic there.

Binswanger, Herbert (1900-1975), was lecturer in psychiatry and first assistant in the Burghölzli Psychiatric Hospital at Zurich University. He published Die Psychosen und Möglichkeiten ihrer Interpretation in 1949.

Binswanger, Ludwig (1881-1966), was born into a family well-established in medicine and psychiatry. He studied under Carl Jung and interned under Eugen Bleuler at Zurich University, sharing their interest in schizophrenia. He became adept at insight-oriented therapy after visiting Sigmund Freud in Vienna in 1907, and after the death of his father Robert Binswanger, he took over the running of the Bellevue Clinic in Kreuzlingen in 1911 (the clinic had been founded in 1857 by Ludwig's grandfather). Binswanger maintained a close friendship with Freud until the latter's death. In the early 1920s, Binswanger became interested in the work of Edmund Husserl, Martin Heidegger and Martin Buber, turning increasingly towards an existential rather than a Freudian perspective; he is sometimes called the first existential therapist. In 1942 he published his major work Grundformen und Erkenntnis menschlichen Daseins. In 1956 Binswanger retired from Bellevue but continued to publish until his death.

Binswanger, Otto (1852-1929), was made associate professor of psychiatry and director of the Jena Canton Asylum in 1882; in 1891 he was made professor in psychiatry at Jena University.

Birkhaug, Konrad Elias (1892-?), was a bacteriologist who was associate professor at Rochester University from 1928 until 1934; between 1932 and 1934 he visited the Pasteur Institute in Paris investigating tuberculosis. In 1939 he was based at the Michelsens Institute in Bergen.

Bleuler, Eugen (1857-1939), was director of the Rheinau nursing home near Zurich from 1886 to 1898; and was appointed professor of psychiatry and director of the Burghölzli Psychiatric Hospital at Zurich University, where he served from 1898 to 1927 (succeeding Auguste-Henri Forel). He introduced the term "schizophrenia" in 1908 to describe - and shift the conception of - the disease known as dementia praecox. Bleuler questioned the view of schizophrenia as necessarily caused by irreversible organic deterioration of the brain, holding that it could have psychological causes, and also denied that schizophrenia always led to dementia. The term schizophrenia denoted the "splitting" of the different psychic functions which Bleuler held to be one of the disease's most important characteristics. He emphasised associative disturbances rather than dementia, and introduced two concepts fundamental to the analysis of schizophrenia: autism, denoting the loss of contact with reality, often through fantasy; and ambivalence, denoting the existence of mutually exclusive contradictions within the psyche. Bleuler urged practitioners to seek to understand and interpret the way patients express themselves. He also argued that instead of tying the individual to a cosmos of conventional meanings, obligations and expectations, language serves to provide a shortcut to wish-fulfilments and to spin out a web of private fantasies. 


\section{Biographical Register}

Bleuler was one of the first psychiatrists to apply psychoanalytical methods in his research. An early proponent of Freud's theories, and a long-standing member of the Vienna Psychoanalytic Society, he attempted to show how the mechanisms Freud found in neurotic patients could also be recognised in psychotic patients. He found intrapsychic complexes, as described by Freud, at the root of schizophrenic symptomatology and searched for a theory by which this symptomatology could be related to organic causes. In Bleuler's concept of schizophrenia two strands of psychiatric thinking met - a Kraepelin-inspired nosological framework indicative of a scientific psychiatry and by no means uncontroversial Freudian concepts. The difficulty of reconciling these strands is in part what led Bleuler to widen the symptomatology of schizophrenia, positing schizophrenic disturbances, differing in quantity rather than quality, as part of the panorama of everyday human experience. Latent schizophrenia was also acceptable to Bleuler. This had unforeseen consequences, in that the notion got hijacked by politically-motivated eugenicist discourse in the 1933 German sterilisation law for patients with hereditary diseases. Over the years, Bleuler moved away from Freud and emphasised the hereditary and organic basis of schizophrenia, having incurred much dissent from academic psychiatry. He also published works on hypnotism, subcortical aphasia, moral idiocy, and the physiology of ventricology. He was one of the editors of the Jahrbuch für psychoanalytische Forschung. His textbook, Lehrbuch der Psychiatrie (1916) is considered a classic, and his work on schizophrenia was published as Dementia Praecox: oder, Gruppe der Schizophrenien in 1911.

Bleuler, Manfred (1903-1994), became lecturer at the University of Basel in 1941, specialising in schizophrenia. From 1942 until 1969 he was director of the Burghölzli Psychiatric Hospital at Zurich University. In 1972 he published Die schizophrenen Geistesstörungen im Lichte langjähriger Kranken- und Familiengeschichten (Stuttgart, Thieme), a landmark study that appeared to challenge Eugen Bleuler's later move towards belief in the inexorability of schizophrenic deterioration. It was translated into English in 1978 as The schizophrenic disorders: long-term patient and family studies (New Haven, Yale University Press). Of 208 patients discharged from one hospital twenty years earlier, $20 \%$ were fully recovered and another $30 \%$ were greatly improved. Within a few years, other researchers replicated his findings.

Bogaert, Ludo van (1897-1989), gave his name to Van Bogaert's encephalitis, a rare, chronic and progressive encephalitis in children and adolescents. In 1933 he became director of the Clinical Services and Pathological Laboratory at the newlyestablished Bunge Research Institute in Antwerp, leading the neurological studies there. The Institute expanded after the war but then closed and since 1964 has housed the Centre of Medical Genetics.

Bonnevie, Kristine Elisabeth Heuch (1872-1948), became the first female member of the Norwegian Academy of Science and Letters in 1911, and in 1912 became the first female professor in Norway when she was appointed professor of zoology at the Kongelige Frederiks Universitet (now the University of Oslo) and director of the Zoological Laboratory until 1938. In 1908 she published work which contributed to modern concepts of the structure of chromosomes. In 1916, with three other professors, Bonnevie established a University Institute for Research on Heredity, which she directed until her retirement. 


\section{Biographical Register}

Bouin, Paul (1870-1962), was professor of histology at Strasbourg University from 1919 onwards, and a pioneer of reproductive physiology. His publications include Éléments d'histologie between 1929-32 (2 volumes).

Bouman, Klaas Hermann Beerta (1874-1947), was a doctor from 1905 until 1916 at the Wilhemina Gasthuis in Amsterdam. In 1912 he was lecturer in psychiatry and in 1915 professor of psychiatry and neurology at Amsterdam University.

Boutdendyck, van: possibly Buijtendijk, Frederick Jakobus Johanes (18871974), who was professor of general physiology at Amsterdam and in 1925 professor of physiology at Gröningen. In 1946 he took up the chair of theoretical psychology at the University of Utrecht, and was considered the leader of the Dutch phenomenological school.

Bovet, Pierre (1878-1965), founded the Institut Jean-Jacques Rousseau in Geneva with Eduard Claparède in 1912, and was its director from its inception until 1944. In 1925 Bovet founded the Bureau International de l'Éducation, also in Geneva, of which Jean Piaget was director.

Bronner, Volf Moiseevich (1876-1938), was made professor at the Moscow State Venereological Institute in 1923, where he remained as its director until his death. Daniel O'Brien told Lewis that Bronner was a representative of the Committee on Foreign Relations of the Narkomzdrav (Ministry of Health), and had published La Lutte contre la prostitution en URSS in 1936. ${ }^{1}$

Brouwer, Bernard (1881-1949), was professor in neurology at Amsterdam University from 1923 and became one of the leading neurologists in Holland. Brouwer became rector of the Wilhemina Gasthuis in Amsterdam at the beginning of the German occupation, but resigned in 1946, when he succeeded Cornelius Kappers as director of the Central Institute of Brain Research, where he worked until his death.

Brunswik, Egon (1903-1955), was an assistant in Karl Bühler's Psychological Institute; he established the first psychological laboratory in Turkey while a visiting lecturer in Ankara during 1931-2; and became lecturer at the University of Vienna in 1934. In 1935-6 Brunswik received a Rockefeller fellowship that enabled him to visit the University of California, encouraged by his meeting Edward C Tolman, chairman of the department of psychology at the University, who had visited Vienna in 1933. He became assistant professor of psychology at Berkeley in 1937, and full professor in 1947.

Bühler, Charlotte (1893-1974), see Bühler, Karl

Bühler, Karl (1879-1963), was made associate professor in Münich in 1913 (where he had followed Oswald Kulpe as assistant). In 1916 he married Charlotte Bühler (1893-1974); they went to Vienna in 1922, he as professor of psychology, and she as associate professor, where they remained until 1938. After visiting posts in the USA, and declining an offer of a professorship at Radcliffe College in 1930, Karl Bühler was invited to be professor at the Roman Catholic Fordham University, but

\footnotetext{
${ }^{1}$ Letter from D P O'Brien, Rockefeller Foundation, to Aubrey Lewis, 23 February 1937, p. 8; held by the Lewis family.
} 
the offer was withdrawn when it was found out that the Bühlers had married in a Protestant ceremony. Charlotte Bühler was a pioneer in developmental psychology. She became assistant professor at the newly founded Psychological Institute in Vienna, and later associate professor in 1929. Prolific and popular, she worked on the neglected field of psychology of the young and developmental psychology. Karl became a representative of action- or goal-oriented psychology of the Würzburg school; he achieved renown in the psychology of language, working also on the psychology of perception, developmental psychology and the psychological study of children. After Karl's imprisonment by the Nazis in 1938 and subsequent release, the Bühlers emigrated to the States where they had difficulty finding teaching work. They eventually found positions in Minnesota; Karl taught a little at Clark University and Charlotte at City College New York, but these posts were temporary. Charlotte moved into clinical psychiatry at Minneapolis General Hospital, and eventually the Bühlers moved to California, where Charlotte worked at Los Angeles County General Hospital. Karl became a clinical psychologist at Los Angeles Cedars of Lebanon Hospital, and opened a private clinical practice in Hollywood.

Buscaino, Vito Maria (1887-?), was professor of psychiatry and neurology and director of the Psychiatric and Neurological Clinic at Catania University from 1927 onwards (he was still based there in 1939).

Campbell, Charles Macfie (1876-1943), a student of Adolf Meyer, was later director of the Boston Psychopathic Hospital. He was professor of psychiatry at Harvard and a proponent of the application of psychoanalytic techniques to psychotic illness.

Carp, Eugène Antoine Désiré Emile (1895-?), was professor of psychiatry at Leiden University from 1930 onwards.

Cerletti, Ugo (1877-1963), finished his medical studies in Rome at the laboratory of Giovanni Mingazzini, the chair of neuropathology and director of the psychiatric hospital. After further studies in Heidelberg under Franz Nissl, director of the Laboratory of Clinical Psychiatry, where Emil Kraepelin was professor, Cerletti became assistant at the Psychiatric Clinic in Rome in 1901. He stayed there until the First World War, becoming director of the Anatomo-pathological Department, and working during this time with Kraepelin at the University Clinic in Munich. After the First World War he had several academic psychiatric postings, and in the early 1930s became director of the Neuropsychiatric Clinic in Genoa, where he researched epilepsy. In 1935 he became professor of psychiatry in Rome, and chief of the Clinic for Nervous and Mental Diseases of the University of Rome. In 1936 he worked with his assistants Ferdinando Accornero, Lucio Bini and Lamberto Longhi; Bini realised that one could apply electric shocks to dogs via their temples, which was far less risky than administering such shocks orally and rectally, as previously done. In 1937, Bini spoke on this matter at Max Müller's conference at Münsingen on therapies in schizophrenia, suggesting that the technique might be applicable to humans. He was keen to try it on patients, though the risks were considerable, and invented a machine which enabled shocks to be administered in a fraction of a second. On 18 April 1938 the first electro-shock therapy was given to patients. Results showed that ECT, while not 


\section{Biographical Register}

a cure for schizophrenia, did alleviate symptoms of psychotic illness and allow psychotics to function normally. Cerletti then mobilised a vast research project on the method; it became clear that the best results came about when applied to the manicdepressive psychoses rather than schizophrenia. Electro-shock became widely used after the Second World War; technical improvements introduced by others as of 1955 led to its application spreading further. From the 1960s onwards, however, it became implicated in anti-psychiatry protests amidst concerns that it was being excessively and inappropriately used.

Chiari, Hans (1851-1916), was a pathologist who worked in Prague until 1906 when he was appointed professor of pathological anatomy in Strasbourg, where he remained until his death.

Chorobski, Jerzy (?-?), was, according to Daniel O'Brien, a former Rockefeller Fellow working with Professor Orzechowski, the professor of neurology and psychiatry at Warsaw. ${ }^{2}$

Claparède, Eduard (1873-1940), was professor at the Science Faculty in Geneva from 1928, and the founder with Pierre Bovet in 1912 of the Jean-Jacques Rousseau Institute, around which the "Geneva School" - which included Jean Piaget - developed. The institute later became the Institute for Educational Sciences.

Claude, Henri Charles Jules (1869-1945), was professor of psychiatry at the Paris Faculty in 1922 until 1939. In the 1930s he was director of the Clinic of Mental Diseases at Hôpital Sainte-Anne. He introduced the biological therapies of Julius Wagner-Jauregg, Manfred Sakel and Ladislas von Meduna into France; encouraged the founding of the Groupe de l'Évolution Psychiatrique; and ensured that psychiatry became a compulsory part of the French medical curriculum. He opened the door to psychoanalysis in his clinic and was editor of L'Encéphale. Claude's syndrome is a mid-brain syndrome with oculo-motor paresis and hemiataxia (Revue Neurologique, 1912). His many publications include Précis de pathologie générale, with Jean Camus (1909), Psychiatrie médico-légale (1932); Éléments de criminologie psychiatrique (1936); Les états anxieux (1938).

Dahlberg: this could be Nathaniel Dahlberg, born in 1874. Daniel O'Brien describes Dahlberg as the director of the Institute of Race Biology in Uppsala. ${ }^{3}$

\section{Davidenkoff, see Davidenkov, Sergey Nikolaevich}

Davidenkov, Sergey Nikolaevich (1880-1961), held from 1920 to 1925 the chair of neurological diseases at the University of Baku. In 1925 he became principal consultant in charge of the Neurological Department for Professional Diseases in the Institute "V. A. Obuha" in Moscow. In 1932 he was appointed professor of neurological disease at the State Institute of Postgraduate Education for Doctors "S. M. Kirova" in Leningrad.

\footnotetext{
${ }^{2}$ Letter from D P O'Brien, Rockefeller Foundation, to Aubrey Lewis, 23 February 1937, p. 7; held by the Lewis family.

${ }^{3}$ Ibid., p. 10.
} 


\section{Biographical Register}

Dechaume: there is an M Dechaume (1897-?) who was a forensic pathologist at Paris University, and wrote a book in 1937 with L Dérobert called L'Expertise en stomatologie.

de Sanctis, Sante (1862-1935), was professor of experimental psychology at the Medical Faculty in Rome from 1905 until his directorship of the Neuropsychiatric Clinic upon Giovanni Mingazzini's death. In 1930 he was nominated president of the Italian League of Hygiene and Mental Prophylaxis. In 1930 he also took over the directorship of the Clinic of Nervous and Mental Diseases in Rome (Mingazzini had fused the institutes of psychiatry and neurology in 1919).

de Vecchi, Bindo (1877-1936), became professor of pathological anatomy at Perugia from 1920 to 1923; he taught this subject at Sassari and Catania between 1923 and 1924; in 1925 he took up the chair of pathological anatomy at Florence University. He became rector of the university in 1930 .

D'Hollander, Fernand (1878-1952), was professor of psychiatry at Louvain from 1920 until 1950; he was director of the Psychiatric Institute from 1926 onwards and wrote Manuel de psychiatrie in 1942.

di Tullio, Benigno (?-?), wrote La criminalità come problema medico-sociale (1951).

Divry, Paul (1889-1967), was professor of psychiatry and neurology and director of the Psychiatric and Neurological Clinic at Liège University from 1925 onwards. An eponym associated with him is the van Bogaert-Divry syndrome, a familial syndrome characterised by angiomatosis of skin and cerebral meninges with progressive demyelinisation of white matter, hemianopsia and cutis marmorata. In 1925 he worked at the Dispensaire d'Hygiène Mentale in Liège.

Dumas, Georges (1866-1946), was professor of experimental psychology at the Sorbonne in 1913, and taught until 1942 as a psychologist and professor at the Laboratory of Psychology of the Psychiatric Clinic at the Hôpital Sainte-Anne in Paris. He was founder of the Société de Psychologie de Paris and founded with Pierre Janet the Journal de Psychologie Normale et Pathologique. His publications include Traité de psychologie (1923).

Durig, Arnold (1872-1961), was professor of physiology and director of the Physiological Institute at Vienna University from 1918 onwards. He published on muscular physiology, metabolism, sport and work physiology.

Economo, Constantin von (1876-1931), was a student of Julius Wagner-Jauregg and became a professor of psychiatry and neurology from 1921 in Vienna. He discovered the chewing, swallowing and sleep centres in the brain (Über den Schlaf, 1925), did lasting work on encephalitis lethargica and promoted the collection and study of outstanding brains. In 1931, he founded the Institute for Brain Research in the Clinic for Psychiatry and Nervous Diseases in Vienna.

Eppinger, Hans (1879-1946), was professor of medicine and director of the Medical Clinic at Vienna University from 1933 onwards, although he was called to Moscow in 1936 when Stalin fell ill; after 1945 he worked as a doctor for the Soviet high command. 


\section{Biographical Register}

Epstein, Emil (1875-1951), was lecturer in General Pathology at Vienna University and director of the Franz Josef Hospital Sero-diagnostic Institute.

Essen, van: possibly Jan van Essen (?-?), who in 1918 is described as a physiotherapist in Amsterdam.

Ey, Henri (1900-1977), was chief doctor of the psychiatric hospitals in Paris in 1933; and while he presided over the Syndicate of Doctors of Psychiatric Hospitals, doctors in these hospitals gained a status equal to that of other hospital doctors. His actions also ensured a more discriminate use of obligatory internment of the mentally ill. He collaborated with Maurice Merleau-Ponty, Paul Ricoeur, Jean Hippolyte, and was involved with Jacques Lacan's École Française de Psychanalyse, known as the École Freudienne de Paris. Ey organised the first World Congress of Psychiatry in Paris in 1950.

Fabritius, Harald August (1877-?), was made professor at Helsingfors University in 1925. He was president of the Helsinki Psychiatric Congress in 1929.

Federn, Paul (1871-1950), was a doctor and psychoanalyst, who, having studied medicine in Vienna, worked in Vienna's General Hospital, advocating psychoanalysis as a medical treatment. He emigrated in 1938; from 1946 he worked as a training analyst in New York. He published Zur Psychologie der Revolution: die vaterlose Gesellschaft (1919), and Ego psychology and the psychoses was published posthumously (1952). He committed suicide in 1950.

Fessard, Alfred (?-?), became Professor Henri Piéron's collaborator in 1932; in 1936 he was joint director of the École des Hautes Études, and in that year published Recherches sur l'activité rythmique des nerfs isolés. Fessard was made professor of general neurophysiology at the Collège de France in 1949, a post created for him.

Fog, Mogens (1904-?), was based at the Municipal State Hospital in Copenhagen, at the laboratory of medical physiology; and then was professor and medical superintendent in the Department for Nervous Diseases at the State Hospital in Copenhagen.

Forel, Auguste-Henri (1848-1931), was appointed professor of psychiatry at the University of Zurich Medical School in 1879, as well as director of the Burghölzli Psychiatric Hospital at the University of Zurich (until 1898), which he helped make a renowned institution. Forel undertook work on the neuron theory which, together with Wilhelm His and Fridtjof Nansen, led to the modern neuron theory. In 1889, Forel founded the Asile d'Ellikon, an institute at Zurich for the medical treatment of alcoholism, and he had considerable influence on reforms in psychiatry and the penal code. He was interested in hypnotism and was involved in social reform as well as in sexual health.

Forel, O-L (?-?), was at Prangins, near Nyon in Switzerland, in 1931.

Fragnito, Onofrio (1871-1959), was professor of neuropathology and director of the Neuropathological Clinic at Naples University from 1927 onwards.

Freud, Anna (1895-1982), was the youngest daughter of Sigmund Freud. She trained as a primary school teacher and in psychoanalysis, becoming a member of the Vienna Psychoanalytic Society in 1922. During her early years in Vienna, she initiated the 


\section{Biographical Register}

application of psychoanalysis to the treatment of children, and then to education and child rearing. She was general secretary of the International Psychoanalytic Association between 1927 and 1934, and in 1935 became director of the Vienna Psychoanalytical Training Institute. In 1938 she emigrated with Sigmund Freud to London, where the conflict between her views and methods and those of Melanie Klein threatened to split the British Psychoanalytical Society. Anna Freud established, during the war years, the Hampstead War Nurseries, and after the war founded the Hampstead Child Therapy Course and Clinic, of which she was director. She lectured widely throughout Europe and the United States and in 1973 was made honorary president of the International Psychoanalytic Association. A prolific writer in her own right, she also collaborated with James Strachey in the preparation of the standard edition of the Complete psychological works of Sigmund Freud, and was also an editor of The Psychoanalytic Study of the Child.

Friedheim, Ernst (1899-1989), specialised in microbiology, cell biology and physical chemistry before becoming professor at the Medical Faculty in Geneva in 1931. He was a pioneer of the chemotherapy of parasitical diseases, publishing work on the treatment of sleeping sickness.

Gamper, Eduard (1887-1938), was made associate professor at the University of Innsbruck; in 1930 he was made professor of psychiatry and neurology at the German University in Prague, where he stayed until his death.

Gannushkin, P B (?-?), was director of the Psychiatric Clinic in Moscow and considered the leading figure in Soviet psychiatry until his death. He was a strong supporter of the organisation of psychiatric services and wards in general hospitals. Daniel O'Brien wrote to Lewis that he had done important work on schizophrenia. ${ }^{4}$ Psychopathological symptomatology was published in 1933.

Gaucher: this could be Philippe Charles Ernest Gaucher (1854-1918) who became head of the Charite laboratory in 1885, physician of the Paris Hospitals in 1886 and agrégé of the Faculty in 1892. In 1902 he was appointed clinical professor of cutaneous and syphilitic diseases. He worked on, amongst other things, the treatment of diphtheria, chronic autointoxication, and skin disease.

Gehuchten, Paul van (1893-?), was professor of neurology at the University of Louvain in 1936. His father, Arthur van Gehuchten (1861-1941) was chair of neurology at Louvain.

Gemelli, Agostino (1878-1959), was made professor of applied psychology and rector at the Sacred Heart University in Milan in 1924, which he had founded in 1921 and where he had opened a psychological laboratory. In 1937 he was made director of the Centre of Studies of Research in Medical Aeronautics of the Air Ministry in 1937. In 1920 he founded, with Federico Kiesow, the Archivio Italiano di Psicologia. In 1936 he was made president of the Accademia Pontificale delle Scienze.

Georgi, F (1893-1965), worked in Freiburg, Frankfurt, Heidelberg and Breslau before returning to Switzerland in 1933, where he worked in Bern and at Yverdon until 1946.

\footnotetext{
${ }^{4}$ Letter from D P O'Brien, Rockefeller Foundation, to Aubrey Lewis, 23 February 1937, p. 8; held by the Lewis family.
} 


\section{Biographical Register}

At Yverdon he was head of the psychiatric clinic; in 1946 he was made chief assistant at the Psychiatric University Clinic in Basel. He was made professor of neurology there in 1955.

Gerstmann, Josef (1887-1969), was professor of neurology and psychiatry in Vienna in 1938 when Alan Gregg of the Rockefeller Foundation visited him; his specialty was brain pathology. Gregg suggests that at the time of his visit Gerstmann was considering applying for American citizenship. ${ }^{5}$

Gersuni might be Grigorij Viktorovic Gersuni (1905-1992), a physiologist.

Gilarowsky might be Giljarovsky, Vasilik Alekseevic (1875-1958), a professor of psychiatry, who is possibly the person who published, with Z A Solevava and A I Vinokurova, Problems of psycho-neurology of children and adolescents in 1936.

Ginglinger, Albert (1899-1956), was an intern at Strasbourg in 1924; he became an agrégé in 1946, and succeeded Raymond Keller as chair of the Gynaecological Clinic in 1953.

Gjessing, Rolv Ragnvaldsson (1887-?), became director and chief psychiatrist at the Dikemark Asylum in Oslo in 1929. He was president of the Norwegian Psychiatric Society from 1932 .

Gorter, Evert (1881-1954), was lecturer in paediatrics at Leiden University, then professor of paediatrics at Ghent University and chief physician at the Paediatric Clinic.

Granit, Ragnar Arthur (1900-?), became a lecturer in physiology at Helsinki University from 1929 onwards, was a research fellow at the University of Philadelphia from 1929 to 1931; became professor of physiology at Dorpat University in 1932; received a fellowship at Exeter College, Oxford, in 1934 and according to Daniel O'Brien, was "recently appointed" head of physiology in Helsingfors. ${ }^{6}$

Grünthal (?-?), was a displaced German who worked in the neuropathology department of Jakob Klaesi's university psychiatric service at Waldau-Bern. ${ }^{7} \mathrm{He}$ directed the Institute of Cerebral Anatomo-Pathology there and was known for his work on senile dementia and Korsakoff's syndrome.

Guillain, Georges Charles (1876-1961), was awarded the professorship of neurology at the Clinic for Nervous Diseases in the Faculty of Medicine in Paris in 1923, and he held the post until his retirement in 1943. His publications include Études neurologiques (1922-39).

Guiraud, Paul (?-?)), was, in 1950, chief doctor at the Hôpital Sainte-Anne in Paris.

Gurevitsch could be one of the following:

Gurevic, Ansel Lejrzerovic (1900?-?), the owner of a bacteriological laboratory.

Gurevic, Michail Osipovic (1878-1953), a professor of psychiatry.

Gurevic, Nikolaj Illic (1871-1960), a professor of surgery.

\footnotetext{
${ }^{5}$ Alan Gregg officer's diary, 29 June 1938, RG 12.1, box 21, RFA, RAC.

${ }^{6}$ Letter from D P O'Brien, Rockefeller Foundation, to Aubrey Lewis, 23 February 1937, p. 9; held by the Lewis family.

${ }^{7}$ Ibid., p. 4.
} 


\section{Biographical Register}

Hadorn, Walter (1898-1986), was director of the Department of Internal Medicine at Tiefenau Hospital in Bern from 1933.

Hammerstein, see Hammersten, Einar

Hammersten, Einar (1889-1968), was professor of chemistry and pharmacy at the Karolinska Institute in Stockholm from 1928 to 1957.

Hartmann, Heinz (1894-1970), was a psychoanalyst associated with the Psychiatric Clinic at the University of Vienna who was one of the last to receive a training analysis from Sigmund Freud, and who, after emigrating to the USA, became known as the "American prime minister of analysis". He, Ernst Kris and Rudolf Löwenstein were key figures in ego psychology in the 1950s and 1960s, through whose work psychoanalysis entered academic medicine and psychology.

Haskoveç, see Haškovec, Ladislav

Haškovec, Ladislav (1866-1944), became professor of nervous diseases at the Psychiatric Clinic in Prague in 1919, and held the neurological chair at the Czech University in Prague until his emeritus professorship in 1936. A pioneer of neurology in Czechoslovakia, he was the first to establish it separately from internal medicine, and opened the first neurological clinic in the University in 1926. In 1935 he was vice-president of the Second International Neurologists' Congress in London.

Hasselt, Sjierd Folkert Willem van (1868-1934).

Herlitzka, Amadeo (1872-1949), was made professor of physiology at Turin University from 1910; he was exiled in 1940 to Argentina, and resumed his chair in Turin in 1946.

Hess, Walter Rudolf (1881-1973), was made director of the Physiological Institute at Zurich in 1917, a post he kept until 1951. In 1931 he set up the Jungfraujoch International Research Institute, and received the Nobel Prize in Medicine or Physiology in 1949 for his work on the central coordination of the vegetative organs.

Heuyer, Georges (1884-1977), was, in 1930, in charge of the service at the Hospital for Sick Children at the Sancelmoz Sanatorium in Haute-Savoie. He was a pioneer of child psychiatry, and much involved in legal psychiatry.

Heymans, Corneille (1892-1968), was professor of pharmacology and pharmacodynamics at Ghent University from 1922. He became director of the Jean-François Heymans Institute of Pharmacology and Therapeutics at the same university, J F Heymans being his father. He received the 1938 Nobel Prize for Physiology or Medicine for his investigations into breathing control.

Hill, Archibald Vivian (1886-1977), became university lecturer at Cambridge in physical chemistry in 1914, and was then appointed Brackenburg Professor of Physiology at Manchester University in 1920. From 1923 until 1925 he was Jodrell Professor of Physiology at University College London, and was in charge of the Biophysics Laboratory there until 1952. His many publications include Muscular activity (1926) and Muscular movement in man (1927).

Hoff, Hans (1897-1969), was made Otto Pötzl's assistant at the PsychiatricNeurological Clinic in Vienna in 1928. In 1936 he became director of the Neurological 


\section{Biographical Register}

Division of the Vienna Policlinic, and in 1938 emigrated to Baghdad as professor of neurology and psychiatry at the Royal Medical School. From 1942 he was assistant professor at the Neurological Institute of Columbia University in New York. In 1950 he returned to Vienna University as professor of neurology.

Hojer, Joan Axel (1890-?), was made assistant professor of experimental pathology at the Karolinska Institute in Stockholm in 1925; then assistant professor of hygiene at Lund University in 1927. In 1930 he was medical officer of health in Malmö in 1930; and director of the General State Medical Board from 1935.

Horst, van der: an $L$ van der Horst was director of the Valerius Clinic of Psychiatry in Amsterdam. This is possibly the person who pioneered the field of medical psychology based on the Gröningen school, dealing with the investigation of temperaments and character-types, very much under the influence of the German school of Kretschmer.

Ivanov-Smolensky, Anatoly Georgievich (1895-?), is described by Daniel O'Brien as being in charge of the psychiatric clinic in Leningrad, ${ }^{8}$ and is credited with extending conditioned reflex theory.

Jackson, John Hughlings (1835-1911), became interested in neurology while a staff member at the National Hospital, Queen Square, in London, where he studied seizures and elaborated principles that explained paroxysmal seizures. He also postulated evolutionary levels of the sensory-motor mechanisms. He exerted a considerable influence on neurology, psychiatry and psychology.

Jacobowsky, probably Jacobovsky (?-?), who was professor of psychiatry at Uppsala.

Jaksch von Wartenhorst, Rudolf Ritter (1855-1947), was a lecturer from 1884 in medical pathology and therapy at the University of Vienna. In 1887 he became associate professor of children's medicine and director of the University Children's Clinic in Graz; he was made professor of internal medicine and director of the Children's Clinic at the German University in Prague in 1889, becoming emeritus professor in 1925.

Jensen, Edmund Zeuthen (1861-1950).

Jong, de (?-?), Daniel O'Brien describes him as head of laboratories at the Neurological Clinic in Amsterdam where Bernard Brouwer was the director. ${ }^{9}$

Kalinowski, see Kalinowsky, Lothar

Kalinowsky, Lothar (1899-?), left Germany in 1933 for Italy; in Rome he witnessed the early ECT experiments on patients at Ugo Cerletti's clinic, and in 1939 introduced the method to the Hôpital Sainte-Anne in Paris. In July 1939 he came to England and helped Sanderson McGregor establish the use of ECT at the Netherne Hospital at Coulsdon. In 1940, Kalinowsky went to the New York State Psychiatric Institute, where he also introduced ECT, and helped insert the method into academic psychiatry as a whole.

\footnotetext{
${ }^{8}$ Letter from D P O'Brien, Rockefeller Foundation, to Aubrey Lewis, 23 February 1937, p. 9; held by the Lewis family.

${ }^{9}$ Ibid., p. 12.
} 


\section{Biographical Register}

Kappers, Cornelius Ubbo Ariëns (1877-1946), was director of the Central Institute for Brain Research in Amsterdam from 1908 until his death, and was associate professor of brain research and comparative neurology at the University of Amsterdam from 1929. His publications include The comparative anatomy of the nervous system of vertebrates, including man, with G C Huber and E C Crosby (1936).

Katzenstein, Erich (1893-?), was first assistant at the Neurological Polyclinic in Zurich and then vice-director of the Neurological Polyclinic and Lecturer at the Medico-Pedagogical Seminary in Zurich.

Kauders, Otto (1893-1949), was made associate professor of psychiatry and neurology at Graz University in 1935; he emigrated to the United States in 1939, resuming his post in Graz in 1945. In 1946 he was made professor and director of the NeurologicalPsychiatric University Clinic in Vienna.

Kemp, Tage (?-?), was lecturer in pathological physiology and director of the Institute of Human Genetics in Copenhagen.

Kiesow, Federico (1858-1940), of Polish origin, went to Turin in 1894, where in 1906 he was appointed to one of the first three chairs in psychology at the Turin Faculty of Letters, and helped diffuse Wilhelm Wundt's ideas through Italy.

Kinberg, Olof (1873-1960), a forensic psychiatrist at the Langbro Asylum from 1921 to 1927 and a lecturer from 1921 to 1939 in legal psychiatry at the Karolinska Institute, Stockholm. From 1934 to 1937 he was director of the Institute for Criminology in Stockholm.

Klaesi, Jakob (1883-?), was professor at Zurich University from 1932, and professor at Bern University from 1933; then he was professor of psychiatry and director of the Asylum at Waldau from 1936 onwards. While staff physician in 1920 in charge of the female ward at Zurich University's psychiatric hospital, the Burghölzli, he began to use a combination of two barbiturates of the Swiss drug firm Hoffman-La Roche marketed as Somnifen, with the aim of curing schizophrenia with prolonged narcosis. Klaesi's results seemed successful, offering the prospect of a cure; and the concept of addressing the brain with profound narcosis gained ground. German doctors used it in the early 1930s to help withdraw addicted patients from morphine. Klaesi's therapy was considered the first treatment which brought about at least transitory improvement in functional psychoses. Several patients, however, collapsed, and some died. A few years later, Max Müller at Münsingen exposed the mortality rate of Somnifen; deep sleep therapy was still used with other, safer, barbiturates, however, especially as a way of making patients accessible to psychotherapy.

Klein, Melanie (1882-1960), trained in Budapest and Berlin before moving to England in 1926. Her ideas challenged Anna Freud's work on children and were influential especially in England and South America. She emphasised pre-Oedipal layers of personality development, holding that Freud neglected the mother's nurturing role in child development. While she was supported by several senior figures in psychoanalytic circles, many of her views met with opposition, and fierce conceptual battles raged in British psychoanalysis. Klein set up a school of child analysis and clashed with Anna Freud on whether children should be treated psychoanalytically in a different manner 


\section{Biographical Register}

from adults; Klein urged that the same technique should be applied, and that play material was the exact equivalent of verbal free associations. After their arrival in London in 1938, Klein became more explicitly separate from the Freuds and was considered by many to be deviationist. In 1943 Ernest Jones organised the 'Controversial Discussions' for debate between Kleinians and their opponents. There followed a division of the British Psychoanalytic Society into Group A, which included the Kleinians and the "middle group" (non-aligned), and Group B, which included Anna Freud and her followers. Klein continued to be highly active and to publish until her death.

Knaus, Hermann (1892-1970), was made professor at the University Women's Clinic in Graz in 1930, and then professor of gynaecology and obstetrics at the German University in Prague from 1934 until 1935, when he was made the director of the University Women's Clinic, where he stayed until 1945. In 1950 he was made head of the gynaecological obstetrics section of the State Hospital in Wien-Lainz. His name is associated with the Knaus-Ogino contraception method, outlined in 1933. After the introduction of synthetic contraception, Knaus was amongst the first to take a stand against the Pill. As an advisor to Pope Paul VI he had a decisive influence in the rejection of the Pill throughout the Catholic Church, while under Pius XX the Knaus-Ogino method had already been endorsed.

Konorski, Jerzy (?-?), worked with Ivan Pavlov in Leningrad from 1931 to 1933, and from 1940 to 1945 he worked at the Primate Research Centre in Sukhumi in the Caucasus. It seems that the Soviet response to Konorski's Conditioned reflexes and neuron organisations in 1948 was not favourable; the label of "revisionist" was removed from his work after Stalin's death, however.

\section{Koupalov, see Kupalov, Pyotr Stepanovich}

Krasnogorsky, Nikolai (1871-1960), was a pupil of Ivan Pavlov, and applied the conditional reflex method to the study of children; his later work focused on language formation in children.

Krayenbuhl, Hugo Alfred (1902-?), ran a neurosurgery department in Zurich at the time of Lewis's visit. Later in his career, he was director of the University Children's Clinic in Zurich.

Kris, Ernst (1900-1957), was an art historian based at the History of Art Museum in Vienna from 1922; he became acquainted with Sigmund Freud, and had training analysis with Helene Deutsch, becoming a member of the Vienna Psychoanalytic Association in 1930. With Robert Wälder he was editor-in-chief of the psychoanalytic magazine Imago. He emigrated to London in 1938, and then lived in New York from 1940, as professor at the New School for Social Research, becoming a child psychologist at Yale University from 1951. He became known as one of the triumvirate, with Heinz Hartmann and Otto Löwenstein, reigning over ego psychology in the 1950s and 1960s.

Kroll, M B (?-?), was director of the Neurological Clinic in Moscow at the time of Lewis's visit.

Kronfeld, Arthur (1886-1941), led, as of 1926, a psychotherapeutic practice in Berlin and in 1928 he founded, with E Kretschmer, the Allgemeine Artzliche Gesellschaft für 


\section{Biographical Register}

Psychotherapie. He was the first lecturer in psychotherapy at the Charite in Berlin in 1933. He emigrated in 1935 to Switzerland, but was called to Moscow in 1936 and became leader of the section for experimental therapy at the P B Gannushkin Psychiatric Research Institute, where the treatment of schizophrenia was his focus. During the German winter offensive of 1941 he and his wife took their own lives. His publications include Sexualpsychopathologie (1923) and Die gegenwäertigen Probleme der Lehre von der Schizophrenie (1936).

Kupalov, Pyotr Stepanovich (1888-?), was professor of physiology at the Leningrad Medical Institute in the late 1930s. Kupalov continued his teacher Ivan Pavlov's line of work at the Institute of Experimental Medicine in Leningrad.

Lagache, Daniel (1903-1972), had worked under Paul Guiraud and Georges Heuyer, and in 1955 became professor at the Sorbonne, as well as president of the French Psychoanalytic Society.

Laignel-Lavastine, Paul-Marie Maxime (1874-1953), was made Chef de Clinique at the Laënnec hospital in Paris in 1919. In 1924 he went to La Pitié, and from 1931-9 held the chair of history of medicine at the Paris Faculty. In 1939 he received the chair of the Clinique des Maladies Mentales, succeeding Henri Claude. He retired from clinical work in 1943. Laignel-Lavastine was also well known for his work in legal medicine and criminology, as well as for his writings in the history of medicine.

Lapicque, Louis (1866-1952), was head of the Department of General Physiology at the Natural Science Faculty in Paris. He linked the intensity of a stimulation and the length of its application into a general law of the nervous system and muscular excitation; chronaxy is the minimum interval of time necessary to electrically stimulate a muscle or nerve fibre, using twice the minimum current needed to elicit a threshold response. Lapicque was director of the Institut Marey from 1936 to 1941.

Laruelle (?-?), ran, according to Daniel O'Brien, the Centre Neurologique de Bruxelles. The research emphasis, states O'Brien, was on brain architectonics, with interesting work being done on degenerative tracts in the central nervous system. ${ }^{10}$

Lépine, Jean (1876-1967), was made professor of neurology and psychiatry at Lyons University in 1911.

Leriche, René (1879-1955), was professor of the surgical clinic at the Faculty of Medicine in Strasbourg from 1927. He was chair of medicine at the Collège de France in 1937 and continued to practise in Strasbourg.

Levi, Giuseppe (1872-1965), became professor in anatomy at Turin University from 1919, after having been at Sassari and Palermo Universities. He was director of the Anatomical Institute in Turin when Lewis visited.

Levit, Solomon Grigorjevich (1894-?), was chief of the Department of Genetics at the Maxim Gorky Medico-Genetical Research Institute in Moscow from 1928 onwards, and director of the Institute from 1930 onwards. Levit was expelled from the Communist Party in 1936, accused of holding pro-Nazi biological views.

\footnotetext{
${ }^{10}$ Letter from D P O'Brien, Rockefeller Foundation, to Aubrey Lewis, 23 February 1937, p. 3; held by the Lewis family.
} 


\section{Biographical Register}

\section{Levitt, see Levit, Solomon Grigorjevich}

\section{L'hermitte see Lhermitte, Jacques Jean}

Lhermitte, Jacques Jean (1877-1959), was professor of psychiatry at Paris in 1922. He was a doctor at the Hospice Paul-Brousse from at least the time Lewis met him until the 1960s and head of the Foundation Dejerine.

Liljestrand, Göran (1886-1968), was professor of pharmacology and director of pharmacology at the Karolinska Institute in Stockholm from 1927 onwards.

\section{Löewenstein, see Löwenstein, Otto}

Lombroso, Ugo (1877-1952), was made professor and director of the Physiological Institute at Palermo University in 1926. At the time of Lewis's visit he was professor and director of the Institute of Physiology at Genoa University.

London, Efim Semenovich (1869-1939), became professor for pathological anatomy at the University, the Veterinary Institute and the Institute of Further Education in Leningrad in 1919. He also worked at the Leningrad University Institute for Experimental Medicine (in the section on the pathophysiology of metabolism), and was made chair of biochemistry at the Institute for Medical Education in Leningrad.

Löwenstein, Otto (1889-1965), became professor of neurology and psychiatry at Bonn in 1931. He founded the first Child Psychiatry Clinic in 1926 in the Rhein County Asylum in 1926, of which he was director until his emigration to Switzerland in 1933. From then until 1938 he was consulting physician at the Clinique La Metairie, in Nyon. In 1939 Löwenstein went to the United States and became professor in neurology at New York University, teaching there until 1947, and until 1962 at Columbia University as research professor in ophthalmology. His specialty was the physiology and pathology of eye pupil movements, which he urged as having an indicatory function for diseases of the central nervous system. His publications include Die Störungen des Lichtreflexes der Pupille bei den lütischen Erkrankungen des Zentralnervensystems in 1935.

Lugaro, Ernesto (1870-1940), was head of the Psychiatric Clinic in Turin in 1911, and in 1927 of the Neurological Clinic. He was editor of the Rivista di patologia nervosa e mentale from its foundation, and was professor of psychiatry at Turin at the time of Lewis's trip.

Luria, Alexander Romanovich (1902-1977), established the Kazan Psychoanalytic Association while still a student. His early research sought to establish methods for assessing Freudian ideas about abnormalities of thought and the effects of fatigue on mental processes. In 1923 he won a position at the Institute of Psychology in Moscow, where he developed a psychodiagnostic technique called the "combined motor method" for diagnosing individual subjects' thought processes. The book describing these studies was not published in Russian until 2002; it was associated with psychoanalytic theorizing disapproved of during the Soviet period. In 1935 Luria met L S Vygotsky and together with him and A N Leontiev, Luria sought to establish a "cultural", "historical" psychology. In the late 1930s, however, Luria entered medical school and worked on aphasia - largely to remove himself from public view during Stalin's purges. During the Second World War he researched brain function and brain lesions. After the 


\section{Biographical Register}

war he continued in neuropsychology, although he was removed for several years from the Institute of Neurosurgery due to anti-semitic repression. Resuming in the 1950s, he pursued work in this field until his death.

Lutz, Jakob (1903-?), after studies in the USA in 1937 and 1938, was made lecturer in psychiatry and neurology at Zurich University. He was head doctor of the Psychiatric Policlinic for Children and Adolescents and of the Children's Department in Stephansburg.

Lysholm, Erik (1891-?), was lecturer and assistant professor in Radiology at Stockholm University from 1931 onwards. He published several works on neurological and general radiology. In 1939 he was based at the Serafimer Hospital in Stockholm.

\section{Lyssolm, see Lysholm, Erik}

Maier, Hans Wolfgang (1882-1945), was first assistant at the Psychiatric Clinic in Zurich between 1910 and 1927; he became professor, succeeding Eugen Bleuler, and director of the Burghölzli Psychiatric Hospital at Zurich University from 1927 onwards. He retired in 1941. At the time of Lewis's visit, Maier was, according to Daniel O'Brien, interested in the insulin treatment of schizophrenia and the use of sleep therapy. ${ }^{11}$ Maier is credited with opening the first maisons d'observation for children at the Burghölzli Psychiatric Hospital, Zurich, in 1920, which eventually extended beyond Switzerland.

Marburg, Otto (1874-1948), was made professor of neurology and director of the Vienna Neurological Institute in 1919. After the Anschluss of Austria in 1938, he emigrated to New York where he was professor at the College of Physicians and Surgeons of Columbia University.

Margaria, Rodolfo (1901-?), was made professor of physiology at Pavia University a few months before Lewis's visit, having been professor at Ferrara previously. In 1950 he was professor of human physiology at the University of Milan.

Meduna, Ladislas von (1896-1964), pioneered the use of camphor, and then cardiazol, as a means of producing seizures which would abate symptoms of schizophrenia, publishing his findings in 1935. Eventually it was felt that the techniques were unreliable in producing fits, also causing too much anxiety in patients. In the 1930s and 1940s cardiazol was much used in the United States but eventually more or less discarded. Meduna trained in neuropathology in 1923-6 at Budapest's Interacademic Institute for Brain Research, and then followed his chief Karl Schaffer to the university psychiatry department. In 1939 Meduna went to Chicago, becoming professor at Loloya University and then at the University of Illinois Medical School, where he worked on carbon-dioxide therapy.

Meyer, Adolf (1866-1950), studied in Zurich, and then Paris, Edinburgh, London and Vienna before going to the United States in 1892, where he worked in psychology and neurology in Chicago. From 1895 to 1902 he was lecturer at Clark University in Worcester, Massachusetts; from 1902 to 1909 he was director of the Pathology

\footnotetext{
${ }^{11}$ Letter from D P O'Brien, Rockefeller Foundation, to Aubrey Lewis, 23 February 1937, p. 4; held by the Lewis family.
} 


\section{Biographical Register}

Institute of State Hospitals in New York and professor of psychiatry from 1904 until 1909 at Cornell University Medical School. From 1910 onwards he was professor at Johns Hopkins University in Baltimore and chief psychiatrist of the Johns Hopkins Hospital. Meyer was a highly influential figure in American psychiatry, advocating a unified vision of psychiatry - "psychobiology" - in which psyche and soma are different dimensions of the same entity. Rather than seeing mental illness as a structural defect in a specific location, he saw mental illness as the diminution of an individual's ability to function, with important social aspects to this process, resulting in "maladjustement" or "maladaptation", rather than "insanity". He thereby helped foster the notion of a psychiatry that extended into everyday life concerns, by blurring the boundaries between normality and abnormality, and psychosis and neurosis. $\mathrm{He}$ strongly desired that the study and treatment of mental illness attain the status and legitimacy of general medicine, and argued for the full integration of mental institutions into the emerging university medical schools and hospitals. Meyer held that the so-called functional psychoses (schizophrenia, manic-depression) were reaction patterns of the central nervous system and represented the interplay of three causal factors - heredity, physical disease and emotional development. There was no particular treatment considered a priori appropriate for the improvement of a patient's condition. Meyer's vision heralded the possibility of a single profession of psychiatry, out of the splintered collection of practitioners - asylum-based physicians (the alienists), private-practice neurologists and general practitioners.

Meyer, Hans Horst (1853-1939), was professor of pharmacology and history of medicine in the University of Dorpat in 1881. He taught at Vienna University from 1904 to 1924, where he was rector from 1917 until 1918.

Meyerhof, Otto Fritz (1884-1951), was asked in 1929 to head the newly founded Kaiser Wilhelm Institute for Medical Research at Heidelberg; he emigrated in 1938, becoming director of Research until 1940 at the Institut de Biologie physico-chimique at Paris. In 1940 he emigrated, becoming research professor of physiological chemistry at the University of Pennsylvania. Meyerhof was awarded, together with A V Hill, the Nobel Prize for Physiology or Medicine for 1922, for his discovery of the fixed relationship between the consumption of oxygen and the metabolism of lactic acid in the muscle.

\section{Meyerhoff, see Meyerhof, Otto Fritz}

Meynert, Theodor (1833-1892), was made prosector of the Vienna Asylum in 1866, and in 1870 was appointed director of the Psychiatric Clinic and associate professor of psychiatry. In 1873 he became professor of nervous diseases. He was also a member of the Supreme Committee of Experts for the Ministry of Health. His research on brain anatomy and function established the anatomy of the cerebral cortex; a proponent of the brain as the basis of mental illness, he published Psychiatrie: Klinik der Erkrankungen des Vorderhirns begründet auf dessen Bau, Leistungen und Ernährung in 1884, translated into English as Psychiatry: clinical treatise on diseases of the fore-brain in 1885 . 


\section{Biographical Register}

Minkowski, Eugène (1885-1972), is considered, together with Ludwig Binswanger, the founder of phenomenological psychiatry; Jacques Lacan considered him the introducer of the notion of structure in French psychiatry. Based mostly in France, he participated in the creation in 1925 of L'Evolution Psychiatrique, which fostered interaction between phenomenology, psychoanalysis and psychiatry. In the 1950s his ideas gained influence in the United States and R D Laing quotes Minkowski in The divided self. Minkowski never occupied a significant post, and experienced suspicion and hostility from the French. Post-war, however, Henri Claude opened doors to him at L'Encéphale.

Minkowski, Mieczyslaw (1884-1972), was made associate professor at Zurich University in 1928; he was then director at the Institute for Anatomy of the Brain and Polyclinic for Nervous Diseases and was made head of the Zurich Association of Psychiatry and Neurology. He was also vice-president of the Swiss Neurological Association.

Minor: Lewis writes of a Victor Minor; there is a Lazar Salamowitch Minor (18551942), a Russian neurologist who was, according to Daniel O'Brien, at the Institute of Experimental Medicine in Moscow, and "interested in diagnostic tests for lesions of the central nervous system, but especially in studies of the neuro-physiology of perspiration". ${ }^{12} \mathrm{He}$ is associated with Minor's disease, a syndrome characterised by haemorrhage into the spinal cord and sudden onset of back pain with paraparesis or paraplegia.

Miskolczy, Dezsö (?-?), was a former fellow of the Rockefeller Foundation, who directed the Institute of Psychiatry and Neurology at the University of Szeged. He worked on the histological correlations of schizophrenia. In 1968 he was professor at the Postdoctoral Studies Institute in Budapest.

Mohr, Otto Lous (1886-?), was chief physician at the Biological Station in Oslo University in 1916; at Columbia University in New York between 1918 and 1919, he was made professor of medicine at Oslo University in 1919. In 1920 he was at the Marine Biological Laboratory at Stanford University. In 1934 he was dean of the Medical Faculty at Oslo University. At the time of Lewis's visit he was working on genetics with Kristine Bonnevie in Lund.

Mollaret, Pierre (1898-?), was, when Lewis visited, a doctor at the Hôpitaux de Paris, professor at the Paris Faculty of Medicine and head of Laboratories at the Institut Pasteur.

Monakow, Constantin von (1853-1930), was of Russian origin, but his father was expatriated from Russia to Switzerland; von Monakow studied in Zurich, where he later founded an Institute of Cerebral Anatomy and a neurological policlinic in 1887 and became professor of neurology in 1894. In 1897 he published Gehirnpathologie and a treatise on cerebral localisation. He studied philosophy, psychology and political and social sciences, and elaborated a vast system incorporating biology and neurology into a philosophical vision inspired by the "creative evolution" of Bergson. Introduction

\footnotetext{
${ }^{12}$ Letter from D P O'Brien, Rockefeller Foundation, to Aubrey Lewis, 23 February 1937, p. 8; held by the Lewis family.
} 


\section{Biographical Register}

biologique à l'étude de la neurologie et de la psychopathologie was published with $\mathrm{R}$ Mourgue in 1928. Monakow helped found the Swiss Neurological Society.

Monnier, L M (?-?), is described by Daniel O'Brien as assistant to Professor Lapicque at the Department of General Physiology at the Paris Natural Science Faculty, working on nerve action studies. ${ }^{13}$ In 1964 Monnier was professor of general physiology at the Sorbonne.

Monrad-Krohn, Georg Herman (1884-1964), held various posts in the State Hospital in Oslo, in London at the Middlesex Hospital; the National Hospital for Nervous Diseases, Queen Square; the Maida Vale Hospital for Epilepsy and Nervous Diseases; the LCC Mental Hospital in Bexley; the Bethlem Royal Hospital; and in Paris at La Salpêtrière. He was professor of medicine at Oslo University and chief physician at Oslo University Clinic of Neurology as well as consulting physician at the Norwegian State Epileptic Institute.

Montassut, this may well be Marcel Montassut (b. 1897) who was a doctor at the Hôpital Henri-Rousselle, Paris, under Henri Claude, in the late 1930s.

Morselli, Enrico (1852-1929), was director of the asylum in Macerata and of the psychiatric clinic at the University of Turin in Genoa. He founded the Rivista sperimentale di freniatria; the Rivista di filosofia scientifica and the Rivista di patologia nervosa e mentale.

Morsier, Georges de (1894-?), was a Swiss neurologist associated with, amongst other conditions, de Morsier's syndrome I, a diencephalic lesion appearing in the first decade of life and accompanied by a variety of behavioural, psychomotor and sensory disorders, as well as signs of precocious sexual development.

Mosinger, Michel (1901-?), was professor at the medical faculties of Marseilles and Coimbra universities in 1946.

Müller, H J, see Muller, Hermann Joseph

Muller, Hermann Joseph (1890-1967), became associate professor at Texas University in Austin in 1920, and then professor in 1925. From 1918 his studies of mutation led to his formulation of the chief principles of spontaneous gene mutation and chromosome change as now recognized; in 1927, working with drosophilia, he proved that X-rays are mutagenic, a discovery that became the basis of radiation genetics and for which Muller was awarded the Nobel Prize for Physiology or Medicine in 1946, nineteen years later. In 1932 he worked for a year in Oscar Vogt's Institute in Berlin, and at the request of N I Vavilov, he then went to the Institute of Genetics of the Academy of Sciences of the USSR as senior geneticist, first in Leningrad, later (1934-7) in Moscow. With the rise of the Lysenko anti-genetics movement, he moved to the Institute of Animal Genetics at Edinburgh University (1937-40); from 1940 to 1945 he was at Amherst College where he was professor and where he completed a large-scale experiment showing the relationship of ageing to spontaneous mutations. In 1945 he went to Indiana University's Zoology Department, from where in 1964 he went to the Institute for Advanced Learning in the Medical Sciences in California.

${ }^{13}$ Letter from D P O'Brien, Rockefeller Foundation, to Aubrey Lewis, 23 February 1937, p. 1; held by the Lewis family. 
Müller, Max (1894-1980), worked with Eugen Bleuler in Zurich and then became head doctor and director of the Münsingen Aslyum from 1939. He imported insulin treatment of schizophrenia to Switzerland and was a pioneer of electro-shock but also made psychotherapy a component of psychiatric treatment. From 1954 to 1962 he was professor of psychiatry and head of the University Clinic Waldau bei Bern.

Muralt, Alexander von (1903-1990), was made professor in 1935 of the division of physiology at the University Institute in Bern. He was president of the governing body of the High Alpine Research Institute at Jungfraujoch (1937-73) and in 1942 founded the Swiss Foundation for Biological-Medical Grants. In 1952 he was founder of Swiss National Funds for the Promotion of Scientific Research.

Musatti, Cesare Luigi (1897-1989), was director and professor of experimental psychology at Padua and Urbino universities from 1928; in Padua he worked on Gestalt psychology and Freudian concepts, introducing psychoanalysis to university courses in 1933; due to the racial laws, however, he was suspended from teaching. During the war he directed a laboratory of industrial psychology within a company. In 1948 he returned to academic life as chair of psychiatry in Milan and from 1955 gave new life to the Rivista di psicoanalisi which had been suspended by fascist authorities in 1934 .

Nielsen in Copenhagen could be any of the following:

Nielsen, Karl Rudolf Rasmus (1899-?), who was at Aalborg from 1935 at least until 1939.

Nielsen, Michael (1891-?), who was at Bispebjaerg Hospital and then the Obstetrics Department at the State Hospital in Copenhagen at least until 1933.

Nielsen, Niels Aage (1887-?), who was at the Aarhus Municipal Hospital at least until 1939.

Nielsen, Ove (1888-?), who was a specialist in surgery in Copenhagen from 1927 onwards and was still there in 1939.

Noyons, Adriaan Karel Marie (1878-?), was lecturer in physiology at Utrecht University in 1909; professor of experimental physiology at Leuven University from 1912 to 1927; and then held the same post at Utrecht University from 1927 onwards.

Nunberg, Hermann (1884-1970), studied in Zurich with Eugen Bleuler and Carl Jung, worked at the Zurich University's Burghölzli Psychiatric Hospital and at the Bern Psychiatric Hospital. He worked with Julius Wagner-Jauregg and Otto Pötzl in Vienna; and was a member of the Vienna Psychoanalytic Society from 1915, becoming a training analyst in 1925 . In 1933 he went to the United States, where he was professor of clinical psychiatry at Temple University, Philadelphia. He had his own practice in New York from 1934.

Nyiro, Gyula (?-1966), was professor of psychiatry and director of the Psychiatric Clinic at the University of Budapest. He came to develop a structural dynamic psychiatry theory.

Oberholzer (?-?), was one of the founding members of the Swiss Psychoanalytic Society (founded in 1919).

Oberling, Charles (1895-?), became professor at the Faculty of Medicine in Paris in 1928 and professor at the Faculty of Medicine in Strasbourg in 1937. His publications 
include Précis d'anatomie pathologique (with G Roussy and R Leroux, 2 volumes) in 1933.

\section{Ödegaard, see Ødegård, Ørnulv}

Ødegård, Ørnulv (?-?), was at the Psychiatric Clinic of the University of Oslo from 1932 (where the chief physician was Ragnar Vogt), after having spent some time at the Henry Phipps Psychiatric Clinic in Baltimore. In 1956 he became professor of psychiatry at the University of Oslo and medical superintendent at Gaustad Mental Hospital until 1961; in 1963 he was at the Social Psychiatry Research Institute, Gaustad Hospital.

Olivecrona, Herbert (1891-?), was assistant surgeon-in-chief at the Serafim Hospital in Stockholm from 1925 to 1935 and director from 1935 onwards, as well as professor of neurological surgery at the Karolinska Institute from 1935 onwards.

Opalski (?-?), according to Daniel O'Brien, was a former Rockefeller Fellow working with Professor Orzechowski (the professor of psychiatry and neurology in Warsaw). ${ }^{14}$

Orbeli, Leon Abgarovich (1882-1958), became head of the department of physiology at the Institute of Physical Education in Leningrad in 1918, a post he held until 1957, as well as head of the First Leningrad Medical Institute from 1920 to 1931, and head of the Military Medical Academy from 1925 to 1950 . From 1936 to 1950 he was director of the USSR Academy of Sciences' Pavlov Institute of Physiology and from 1939 to 1950 was director of the Institute of Evolutionary Physiology and Higher Nervous Activity of the USSR Academy of Medical Sciences. From 1942 to 1946 he was Vice-President of the Academy of Sciences. By the time Lewis visited him, he had shown that the autonomic nervous system has the same influence on skeletal as on heart muscles, demonstrating its manifold effects on metabolism throughout the body.

Orzechowski is most likely Orzechowski, Kazimierz (1878-?), professor of neurology at Warsaw University.

Osipov, Viktor Petrovich (1871-1947).

\section{Ossipov, see Osipov, Viktor Petrovich}

Pende, Nicola (1880-1970), was professor of special medical pathology and clinical methodology at Rome University from 1935. Pende had his own BiotypologicalOrthogenic Institute, making films on physical fitness, and he did propaganda work for the fascist government in magazines and radio speeches.

Petrov, Nikolai Nikolaevich (1876-1964), became a professor at Warsaw in 1912 , and in 1913 was at the Petersburg Institute for Medical Education. He later became professor of surgery and director, until 1946, of the Oncological Institute in Leningrad, which he founded in 1926. He also founded the Institute for Experimental Cancer Research at the All-Unions Institute for Experimental Medicine. He was editor of Voprosy onkologii and Vestnik Khirurgi. He was awarded the Order of Lenin, the Stalin Prize and the Lenin Prize.

\footnotetext{
${ }^{14}$ Letter from D P O'Brien, Rockefeller Foundation, to Aubrey Lewis, 23 February 1937, p. 7; held by the Lewis family.
} 


\section{Biographical Register}

Piaget, Jean (1896-1980), a pioneer of development psychology, became director of studies at the Jean-Jacques Rousseau Institute in Geneva in 1921 at the request of Eduard Claparède and Pierre Bovet. He held the chair in the history of scientific thinking at Geneva from 1929 to 1939; was director of the International Bureau of Education from 1929 to 1967 and director of the Institute of Educational Sciences at Geneva from 1932-71; he held the chair in psychology and sociology at Lausanne from 1938 to 1951; the chair of sociology at Geneva from 1939 to 1952 , then that of genetics and experimental psychology from 1940 to 1971. In 1955, he created and then directed the International Centre for Genetic Epistemology until his death.

Pichler, Hans (1877-1949), was made professor of surgery at Vienna University in 1919, and became professor and head of the Vienna Dentistry University Institute in 1930.

Pick, Ernst (1872-1960), became assistant to Richard Paltauf at the Vienna Serotherapeutic Institute from 1899 to 1911 . In 1917 he was made professor, and from 1911 to 1924 was assistant to Horst Meyer, working on experimental pharmacology and toxicology. From 1924 to 1938 he was professor of pharmacology at Vienna University; after the Anschluss of Austria he emigrated to the United States, where from 1939 to 1960 he was professor at Columbia University and adviser to Merck, Sharp and Dohme.

Pienkowski, Stefan Kazimir (1885-?), was professor at Krakow University from 1932 onwards and director of the University Nervous Disease and Psychiatric Clinic.

Piéron, Henri (1881-1964), was a central figure in the Psychophysiology Laboratory at the Sorbonne and the Laboratory of the Sensory Physiology at the Collège de France. On Alfred Binet's death in 1911 he succeeded him as director of the Laboratory of Physiological Psychology. He organised the Institute of Psychology with the help of George Dumas. In 1923 he entered the Collège de France for the chair of physiology of sensation created for him. In 1926 he founded the Laboratory of Sensory Physiology. He was director of the National Institute for Professional Orientation established in 1928.

Podkopaev, Nikolai Aleksandrovich (1892-?) is described by Daniel O'Brien as being, along with Rosenthal, a physiologist at the Institute of Experimental Medicine in Leningrad and at the Academy of Sciences, using the Pavlovian method. ${ }^{15}$

Policard, Albert (1881-1972), was professor of histology in Lyons from 1919 onwards.

Ponzo, Mario (1882-?), succeeded Sante de Sanctis in 1931 as chair of experimental psychology at the Ateneo in Rome.

Pötzl, Otto (1877-1962), was Julius Wagner-Jauregg's successor as professor of psychiatry at Vienna University's Psychiatry Clinic in 1928, after having been professor of psychiatry and neurology at the German University in Prague in 1922. From 1945 he was director of the Clinic. His publications include Die Aphasielehre vom Standpunkte der klinischen Psychiatrie (1928).

\footnotetext{
${ }^{15}$ Letter from D P O'Brien, Rockefeller Foundation, to Aubrey Lewis, 23 February 1937, p. 9; held by the Lewis family.
} 
Propper, N (?-?), is described by Daniel O'Brien as being in Professor M B Kroll's department (the neurological clinic in Moscow); ${ }^{16}$ Propper had recently been to the United States to work with Fulton and had also worked with Adrian at Cambridge between 1935 and 1936. O'Brien calls him a "key man" who studied the pathogenesis of epilepsy.

Querido, Arie (1901-1983), got his MD from Harvard in 1932, having previously trained in physiology with W B Cannon in 1923-4 on a Rockefeller Fellowship. He was - at least in 1950 - director of public health and the hospitals of Amsterdam, at the Department of Public Health, City Health Service in Amsterdam.

Rademaker, Gijsbertus Godefriedus Johannes (1887-1947), was appointed professor of physiology at Leiden in 1928, and in 1946 took up the newly-created chair for neurology at Leiden. His work focused primarily on the physiology of muscle and the nervous system.

Ramer, Karl Torsten (1902-?), was chief doctor at the Children's Psychiatric and Neurological Clinic in Stockholm from 1933 onwards.

Révész, Géza (1878-1955), worked in empirical psychology, especially on sound, language and anxiety. At the time of Lewis's visit, he was interested in the psychopathology of the blind. He is described in The contribution of Holland to the sciences: a symposium (edited by A J Barnouw and B Landheer in 1943) as being the most important empirical psychologist working in Holland at the time.

Rey (?-?), was assistant at the Institut des Sciences de l'Éducation, and a lecturer at the University of Geneva.

Rittmeister could be John Rittmeister (1898-1943), who studied medicine and became interested in Jung, Bakunin and Marx. He had been a conscientious objector in the First World War and from 1929 was a psychoanalyst in Switzerland, where he looked after German emigrants. In 1938 he was chief doctor at the Waldhaus Clinic of Nervous Disease in Berlin; in 1939 he was head of the Policlinic of the German Institute for Psychological Research and Psychotherapy. He helped Jewish patients with emigration and resisted discrimination against homosexuals. Arrested in 1942, he was brought in front of the Reich War Court and sentenced to death.

Rosenthal could be Rozental, Solomon Kondratevic (1890-1955); the Rosenthal Lewis refers to is described by Daniel O'Brien as a pupil of Ivan Pavlov who spent a year with Joseph Barcroft, and who, along with Podkopaev, was a physiologist in Leningrad working at the Institute of Experimental Medicine and the Academy of Sciences. ${ }^{17}$

Rossi, Ottorino (1877-1936), was lecturer in nervous and mental diseases in Sassari in 1911 and in Pavia in 1925. He was professor of psychiatry and neurology there when Lewis visited.

Rotfeld, see Rothfeld, Jakob

\footnotetext{
${ }^{16}$ Letter from D P O'Brien, Rockefeller Foundation, to Aubrey Lewis, 23 February 1937, p. 8; held by the Lewis family.

${ }^{17}$ Ibid., p. 9.
} 
Rothfeld, Jakob (1883-?), was a research student at the Wagner-Jauregg Clinic, Obersteiner Institute and the Nonne Neurological Clinic in Hamburg until 1919; he was assistant and then deputy director of the Lvov Neurological and Psychological Clinic and from 1928 honorary professor at Lvov University.

Röthlin, Ernst (1888-1972), studied medicine, chemistry and physiology in Germany and Switzerland and between 1922 and 1956 led the pharmacological laboratory of Sandoz AG in Basel. He taught from 1934 as professor of pharmacology at the University of Basel and was a founder member of the Swiss Academy of Sciences and the International College of Neuropsychopharmacology.

\section{Rotholin, see Röthlin, Ernst}

Roussy, Gustave (1874-1948), who was Swiss, became a professor at the Paris Medical Faculty in 1910. In 1913 he was chief doctor at the Hospice Paul-Brousse, newly-founded in Villejuif, a post he resumed after the war. He pioneered studies of cancer; a centre within the hospital became the Institut du Cancer de Villejuif. In 1925 he became professor of pathological anatomy and was the doyen of the Faculty of Medicine in Paris in 1933. In 1937 he was named rector of the University of Paris. After his death the Institut du Cancer was renamed the Institut Gustave Roussy.

Rubénovitch: Daniel O'Brien wrote to Lewis about a Peter Rubenovitch who was an assistant to Henri Claude at the Hôpital Sainte-Anne. ${ }^{18}$ There is, however, also a Jacques Roubinovitch (1862-1950) who became Chef de Clinique in psychiatry and a neuropsychiatric doctor at the Paris hospitals, La Salpêtrière and the Hospice Bicêtre; he was also doctor at the Henri-Rousselle psychiatric hospital. It is not clear which one Lewis is referring to.

Rüdin, Ernst (1874-1952), became professor in the University Psychiatric Clinic at Munich in 1915 and from 1917 was head of the Genealogical-Demographic Section of the German Psychiatric Research Institute. In the 1920s he was co-founder of the Society for Race Hygiene and co-editor of the Archivs für Rassen- und Bevolkerungsbiologie. Rüdin was the advocate of what was the precursor to Nazi "racial hygiene". He played a key role in the creation in 1933 of the Law on the Prevention of Offspring with Hereditary Diseases, which provided for compulsory sterilisation. He published Strömungen im Art and Umfang der Sterilisastionspraxis in 1937.

Rümke, Henricus Cornelis (1893-1967), was physician at the Valerius Clinic in Amsterdam until 1927; in 1928 he was chief physician at the Psycho-Neurological Clinic at Amsterdam University and from 1936 was professor of psychiatry at the University.

Rylander, Gösta (1903-?), was a hospital practitioner at the Urological and Psychiatric Clinic in Stockholm. He was at St Eric Hospital from 1930 until 1934, then a doctor at the Psychiatric Clinic of Stockholm University and then chief at the Psychiatric Policlinic of the Serafimer Hospital.

Saethre, see Säthre, Haakon

\footnotetext{
${ }^{18}$ Letter from D P O’Brien, Rockefeller Foundation, to Aubrey Lewis, 23 February 1937, p. 1. held by the Lewis family.
} 


\section{Biographical Register}

Säthre, Haakon (1891-?), was chief doctor at the Psychiatry Department at Ullevaal Hospital from 1933 and then became a specialist in psychiatry at Oslo University.

Sakel, Manfred (1900-1957), discovered, in the late 1920s in Berlin, that recovering morphine addicts had less compulsion for morphine once they came round from coma brought about by insulin shock. In 1933 he went to the Vienna University Psychiatric Clinic under Otto Pötzl, where he began systematically testing the possibility that insulin shock could cure schizophrenia. (It seems that Sakel was not initially aware of previous efforts to treat psychosis with insulin.) In 1936 he went to the USA to treat a wealthy private patient, and stayed on, first as staff member of the New York State Psychiatric Hospital, then in a private practice in Manhattan. Insulin-coma therapy was not adopted uniformly, but was popular in Switzerland and in the Anglo-Saxon world. Max Müller organised a world conference on new therapies for schizophrenia in 1937 and Münsingen became the destination for insulin treatment. Ultimately, however, it was discovered that insulin did not differ in its long-term success rate from barbiturate sleep therapy.

Schaffer, Karoly (?-?), while professor at Budapest University, established a laboratory for research in cerebral pathology.

Scherer, Hans Joachim (1906-1945), was a pioneer in glioma research. A political refugee in Antwerp between 1934 and 1941, he was the first to distinguish primary and secondary glioblastomas. His name is associated with the van Bogaert-Scherer-Epstein syndrome, a familial disorder of metabolism.

Schubert, Gustav (1897-1976), became a lecturer at the German University in Prague in 1928 and in 1943 became professor of physiology there. In 1945 he went to Vienna and until 1950 was professor of physiology at the Veterinary School. From 1950 to 1968 he worked in the Medical Faculty at the University of Vienna.

Snapper, Isidore (1889-1973), was at the Medical University Clinic in Amsterdam from 1919 as professor for propaedeutics and general pathology.

Speranskii, Aleksei Dmitrievich (1887-1958), was professor of pathology and physiology at the Institute of Experimental Medicine in Moscow. He did research on, amongst other topics, the physiology of cerebrospinal fluid.

Staehelin, John Eugen (1891-1969), was assistant and senior doctor at Zurich University's Burghölzli Psychiatric Hospital under Eugen Bleuler from 1919 to 1929; he became director of the Psychiatric Clinic and the Friedmatt Nursing Home in Basel in 1929; from 1929 to 1959 he was professor of psychiatry at Basel University, where he was rector in 1938.

Steck (?-?), undertook work on correlations between constitutional types and the complications of cranial trauma. In 1941 he opened the Grangette Clinic in the Cery asylum, Lausanne, designed initially to receive cranio-cerebral traumatisms, but whose activity subsequently enlarged.

Stern, Lina Solomonovna (1878-1968), was a distinguished Soviet physiologist who pioneered the chemical investigation of physiological processes, most notably in the brain and central nervous system. The author of more than 400 works on medical 


\section{Biographical Register}

and physiological topics, Stern was the first to describe the blood-brain barrier which protects the nerves and spinal fluid from harmful substances in the blood. Stern studied in Geneva, where she became professor of physiology until 1925 when she emigrated to the Soviet Union and was naturalised as a Soviet citizen. She worked at the Moscow Medical Institute on chemical foundations of physiological functions of the nervous system, eventually taking over its directorship. She was the first woman to be admitted to the Academy of Sciences in the Soviet Union. In 1943 she received the Stalin Prize for Scientific Research, but five years later a government purge found her guilty of "rootless cosmopolitanism", a code phrase generally used to stigmatise Jews. Stern was forced to resign from all academic positions. After Stalin's death in 1953 Stern was "rehabilitated" and restored to a position of honour in the Soviet Union, where she remained until her death.

Strömgren, Erik (1909-?), was professor of psychiatry at Copenhagen at the time of Lewis's visit, and worked in genetics.

Svedberg, Theodor (1884-?), was lecturer at the University of Uppsala in 1922. In 1944 he was professor of physical chemistry there. During the 1920s, Svedberg's work on the determination of particle size distribution in solutions of high-molecular organic substances ultimately led to construction of the ultracentrifuge, with which he and Robin Fahraeus, in a famous experiment in 1924, centrifuged haemoglobin. The ultracentrifuge became a tool for characterising and determining the molecular weight of biochemically important substances. Svedberg went on to develop equipment such as the ultramicroscope, the electron microscope and the cyclotron.

Szent-Györgyi von Nagyrapolt, Albert (1893-1986), won the 1937 Nobel Prize for isolating vitamin $\mathrm{C}$. He also discovered flavone or vitamin $\mathrm{P}$, effective against purpura; the protein actin; and vitamin $B_{2}$. Later in his life he explored the origins of cancer. He had received Rockefeller sponsorship to study in Cambridge and in the USA, but in the late 1920s, at the request of the Hungarian minister of education, took the chair of medical chemistry at the University of Szeged. In 1947 he emigrated to the United States.

Szondi, Leopold (1893-1986), was professor of psychopathology at the College for Remedial Education in Budapest in 1927. After being imprisoned for some months in the Bergen-Belsen concentration camp, he fled to Switzerland, where he worked in the psychiatric clinic in Prangins. In 1946 he went to Zurich and in 1959 founded the International Research Community for Schicksalspsychologie - "fate analysis". This stipulated that the various kinds of instincts may be determined by analysing photographs of the mentally ill, psychopaths and neurotics.

\section{Szondy, see Szondi, Leopold}

Tamburini, Augusto (1848-1919), became director of the asylum in Reggio Emilia in 1877 , where he introduced many reforms, and which became the principal training site for psychiatrists. He was one of the first Italian psychiatrists to work on aphasia, and became renowned for his Sulla genesi delle allucinazioni (1880). In 1905 he took over the chair in psychiatry at Rome previously held by Ezio Sciamanna. 


\section{Biographical Register}

Tanzi, Eugenio (1856-1934), worked under Augusto Tamburini in Reggio Emilia, became professor of psychiatry in Caglioni in 1893 and in 1895 succeeded to Tamburini's post where he remained until the end of his career. In 1896 he founded the Rivista di patologia nervosa e mentale, and in 1905 published the Trattato delle malattie mentali, of Kraepelinian inspiration. Along with Augusto Tamburini, he did significant work on hallucinations.

Terni (?-?), is described by Daniel O'Brien as being in charge of the department of histology and embryology at Padua University, and as having done interesting work on tissue cultures of the nervous system. ${ }^{19}$

Theorell, Axel Hugo Teodor (1903-1982), was a Swedish biochemist, awarded the 1955 Nobel Prize for Physiology or Medicine for his contribution to the study of oxidation enzymes. Theorell's work constituted the first detailed description of enzyme activity in which the mechanisms and interaction of "coenzymes" and "apoenzymes" were clearly outlined. Theorell studied medicine at the Karolinska Institute in Stockholm, but polio forced him to abandon practice as a physician and he became a professor and researcher at the University of Uppsala, where he undertook his biochemical studies. In 1937, Theorell took over as director of the Nobel Institute for Biochemistry, a department of the Karolinska Institute. Theorell was also the first to isolate a pure crystalline form of myoglobin, a red-coloured variety of haemoglobin found in muscle fibres. His other notable achievements include the invention of a blood test for drunkenness.

Thomsen, Oluf (1878-1940), was the driving force behind the Institute of Human Genetics in Copenhagen and had been working on blood groupings from the hereditary stand-point, according to Daniel O'Brien. ${ }^{20}$

Tiebout, Petronella Hendrica Catherine (1899-1968), is described by Daniel O'Brien as being at the Neuro-Psychiatric Dispensary of the Office of Hygiene in Amsterdam. ${ }^{21}$

Tschermak-Seysenegg, Armin von (1870-1952), became professor at the College of Veterinary Surgery in Vienna from 1906 until 1913 and was then at the German University in Prague, where he became an emeritus professor in 1939.

Vermeylen (?-?), was, in 1936, professor of psychiatry in Brussels, according to Daniel O'Brien. ${ }^{22}$

Verzár, Fritz (1886-1979), a physiologist in Basel at the time of Lewis's visit, was professor of physiology in Debreczen between 1913 and 1918. He called to Basel in 1930 as professor of physiology and director of the Physiological Institute and became dean of the Medical Faculty there in 1937.

Vincent, Clois (1879-1947), was based at the Hôpital de la Pitié next to La Salpêtrière in Paris, running the clinic in neuro-surgery and neurology.

\footnotetext{
${ }^{19}$ Letter from D P O'Brien, Rockefeller Foundation, to Aubrey Lewis, 23 February 1937, p. 6. held by the Lewis family.

${ }^{20}$ Ibid., p. 11.

${ }^{21}$ Ibid., p. 12.

${ }^{22}$ Ibid., p. 3.
} 


\section{Biographical Register}

Vogt, Ragnar (1870-?), became director of the Gaustad Asylum, Oslo, in 1911 until 1914, was director of the Psychiatric Clinic in Oslo from 1926 and was professor of psychiatry at Oslo when Lewis visited.

Waals, Hermanus Gijsbertus van der (1894-1974), was head clinician in Amsterdam with Klaas H B Bouman. He was one of the founders of the psychoanalytic institute there and was a training analyst for many years. In 1956 he went to Topeka, Kansas, where he was superintendent of the C F Menninger Memorial Hospital.

Wagner-Jauregg, Julius (1857-1940), was head of the Vienna University Psychiatric Clinic from 1893 to 1928 and pioneered fever therapy for the treatment of neurosyphilitic psychosis. Initially injecting tuberculin, he went on to induce malarial fevers in patients. Wagner-Jauregg received the Nobel Prize for Physiology or Medicine in 1927. It eventually became obvious, however, that fever cures were no panacea; moreover, they were dangerous, expensive and cumbersome. His publications include Verhütung und Behandlung progressiven Paralyse durch Impfmalaria (1931) and Mechanismus der Wirkung der Infektions- und Fiebertherapie (1935).

Waldenstrom, Johann Henning (1877-1972), received his doctorate from Stockholm University in 1910, and became lecturer in orthopaedic surgery at the Karolinska Institute in Stockholm before going to Uppsala, where he worked on the relation of pernicious anaemia to the nervous system. ${ }^{23}$

Wälder, Robert (1900-1967), was a lay analyst who became a member of the Vienna Psychoanalytic Society in 1924, when he began publishing his own psychoanalytic work. From 1925 he taught at the Society's training institute and was the Society's librarian from 1928. Wälder was editor, with Ernst Kris, of Imago from 1932 until 1938. That year he emigrated to the United States, teaching and lecturing in Boston and New York, eventually becoming professor of psychoanalysis in the psychiatry department of Jefferson Medical College in Philadelphia.

Walthard, Max (1867-1933), became professor in obstetrics and gynaecology at Bern University in 1903 and then professor at Frankfurt am Main, before going to Zurich University.

Warburg, Erik Johan (1892-?), was possibly chief doctor at the State Hospital in Copenhagen when Lewis visited; by 1939 at least he was professor of internal medicine at Copenhagen University and chief doctor at the State Hospital.

Wigert, Viktor Hjalmar Hugo (1880-1942), was made professor of psychiatry at Lund University in 1923 and went to the Karolinska Institute in Stockholm in 1929.

Wolff, Etienne (?-?), was, in 1936, assistant at the Institute of Embryology and Teratology of the Medical Faculty at Strasbourg University.

Ylppo, see Ylppoe, Arvo

Ylppoe, Arvo (1887-1992), became lecturer at the University of Helsingfors in 1919; in 1921 he was associate professor and in 1925 professor of children's medicine.

\footnotetext{
${ }^{23}$ Letter from D P O'Brien, Rockefeller Foundation, to Aubrey Lewis, 23 February 1937, p. 10; held by the Lewis family.
} 


\section{Biographical Register}

Zalla (?-?), was professor of psychiatry and neurology at Florence.

Ziedses des Plantes, Bernard George (1902-?), Daniel O'Brien describes him as having done work on $\mathrm{x}$-raying the head at the psychiatry department in Utrecht. ${ }^{24}$

${ }^{24}$ Letter from D P O'Brien, Rockefeller Foundation, to Aubrey Lewis, 23 February 1937, p. 12; held by the Lewis family. 